\title{
Formation of new linguistic competences in education space: naming examination
}

\author{
Elena Remchukova ${ }^{1, *}$ and Tatiana Sokolova ${ }^{2}$ \\ ${ }^{1}$ PFUR, Faculty of General and Russian linguistics, 117198, Moscow, Russia \\ ${ }^{2}$ MSLA, Department of Forensic Examinations, 123995, Moscow, Russia
}

\begin{abstract}
The naming examination is a new kind of linguistic examination. The article deals with linguistic aspects of teaching this course in higher school for the special training of experts. In order to form professional competence on naming examination in the process of teaching special attention is paid to studies of theory of nomination and onomastics, to examination of language units from the point of view of component analysis, semantic-stylistic analysis and others, as well as the formation of the skills of work with different lexicographic sources and digital resources and database. In the laboratory course "Applied and mathematical linguistics," the skills of lexico-semantic, morphological, etymological, morphemic, word-formation, phonetic analysis of concrete names are practiced. We focus on the studies of artificial naming patterns, including advertising names, which bring out the creative potential of the Russian language. Creative trends dominate in this area of nomination. Naming examination as a new kind of forensic linguistic examination is taught within the course "Forensic linguistic examination" which accomplishes technical education of students
\end{abstract}

The naming examination is "a procedurally regulated linguistic study of names as voice products, culminating in a conclusion on issues whose resolution requires an application of special knowledge of linguistics, onomastics, judicial Speech Studies and judicial expertology"[1] and a new kind of linguistic examination. A demand for this type of examination today is determined by the need for legal protection of names - not only personal names of citizens, an author's name or pseudonym, but also names as intellectual property. These include trademarks and service marks, trade names, commercial designations, etc.

The problem of legal protection of names affects interests of a wide range of rights' holders, so training of specialists with appropriate knowledge for naming examination has a special place in modern education space. The specificity of training such specialists is that they should undergo a course of the total of legal (civil law, civil and arbitration proceedings) and linguistic training. Stages and components of the latter are discussed in the article.

The competence of experts in the field of naming examination is determined by their level of education (especially in the field of contemporary Russian language), special expert training, expert work experience, experience in solving similar expert problems, individual abilities [2]. The competence of a Speech Studies expert on naming examination must consist of specialized knowledge of general and applied linguistics, onomastics, judicial Speech Studies and judicial expertology. "The unity of integrated nature of all kinds of forensic examinations allowed development of a unified approach to the preparation of legal experts of various specialties within higher education. For this purpose, the Federal State Education Standards of higher professional education(the FSES HPE) of the 1st and 2nd generation on the specialty defined by the FSES HPE 030502.65 "Forensic Examination" were created. Graduates of higher educational institutions in this specialty are being awarded the qualification of a "legal expert" since 2003 [3]. The discipline "Forensic Linguistic Examination"[4] completes the competencies required to carry out professional activities in the field of voice products examination.

Special knowledge is considered as part of the qualification as a complex of knowledge in the field of theory, methodology and practice of a certain type of forensic examination, and completes an expert's competence $[5,6]$. The objective competence of a Speech Studies expert on naming examination must consist of specialized knowledge of general and applied linguistics, onomastics, judicial Speech Studies and judicial expertology. "Special knowledge in the field of judicial Speech Studies constitute the scientific basis of a forensic and expert study of human speech activity products in proceedings, where a Speech scientist can act in two procedural qualities: an expert and a specialist" [7]. It should be noted that the term competence is used in expertology in two meanings: 1) reference that an expert is endowed with by the legislation on forensic

\footnotetext{
Corresponding author: remchukova@pochta.ru
} 
examination; 2) a set of knowledge, skills, activities in the field of theory, methodology and practice of a certain kind of forensic examination (a list of common cultural and professional competences of a Speech Studies expert defined by the FSES HPE 031003.65 "Forensic Examination" qualification of a legal expert). Subjective competence or expert competence is an expert's level of relevant knowledge, including personal attitude to it and to the subject of activity [8].

Linguistics is a basic discipline for a Speech Studies expert. It is linguistic knowledge that forms the basis of special knowledge expertise in naming examination: a professional should be skilled at content and formal analysis of linguistic units of each level (phonetic, morphemic, lexical and grammatical), and have the ability to produce a graphemic analysis of speech units recorded in writing, to identify its contextual links, features of functioning in the discourse.

It is these skills that allow a future expert to evaluate official, that is, non-commercial names (names of streets, metro stations, etc.) in terms of their compliance with contemporary Russian language. Thus, the Law of Moscow № 40-70 ("On the naming of territorial units, streets and metro stations of the city of Moscow") stresses that "...names of territorial units, streets and metro stations of Moscow must meet word-formation, pronunciation and stylistic norms of contemporary Russian literary language. They should be harmonious, pronunciation-friendly, concise and easy to remember". At the same time, errors related to violation of these rules are frequent both in modern and historical toponyms of Moscow. For example, the street Новая Ипатовка (Novaya Ipatovka) received its name in 1920 after a bol'shevik Ipatov, an October Revolution and Civil War participant, who died in 1919, but the derivational model of the name ending in -ка in conjunction with the adjective новая ('new') seems to be indicating the name of a former village. Such cases are subject to the word-formation analysis in the process of formation of students' linguistic competences and at the same time, they focus their attention on failures (and even funny names) that have existed in the history of Moscow, as today awkward toponyms, which should undergo normalization, also occur.

Linguistic analysis of urbanonyms allows understanding of pronunciation rules, since assigning names, one should consider the peculiarities of their pronunciation, for example, use the letter "ë" in order to prevent distortion of names: it is correct to pronounce Улица Мнёвники ('Ulitsa 'Mnyovniki), Хорошёвское шocce (Khoroshyovskoe Shosse), but according to the spelling, many say Мневники (Mnevniki), Хорошевское шоссе (Khoroshevskoe Shosse) . The analysis of failed street names (улица Газовиков Gazovikov Street) can demonstrate a violation of stylistic norms as the word газовик (gazovik - "gas worker") is a reduced, colloquial naming of a gas industry employee.

Thus, teaching the Russian language in the framework of the unit of linguistic disciplines is focused on the formation of students' skills required for practical expert activity. The discipline "General Linguistics and
Contemporary Russian language" refers to the basic disciplines of the professional cycle basic educational program (BEP) (total workload of 8 credits). Its mission is to give students a holistic overview of the main trends in development of linguistics and the conceptual apparatus of general linguistics; structural typology of language and the theory of language universals and, most importantly, - basic knowledge of contemporary Russian language (a system of units of each level, laws of their formation and operation).

At the same time, the structure of linguistic knowledge highlights the theory of nomination [9] and onomastics [10], and among the skills to be formed at students, there are the analysis of linguistic units with component, semantic and stylistic, and other methods [11]; experience with a variety of lexicographical sources, including electronic ones.

A parallel course in the specialization "Foundations of Applied and Mathematical Linguistics" (3 credits) involves practicing specific skills of lexical and semantic, etymological, morphemic, word-formation, morphological and phonetic analysis of specific voice products, including proper names of different categories, used as trademarks, during laboratory courses [12]. Particular attention is paid to study of models of artificial nomination and naming strategies [13], as well as advertising names [14]. This is due to the intensive development of new, linguistic and creative trends in commercial naming as a whole, due to both extralinguistic and proper linguistic reasons (see [15] for details).

Therefore, much of practical work done by students involves in solving of naming problems, identification of problem situations and models of their solution on the basis of knowledge of Russian language, its norms and creative possibilities $[16 ; 17]$. For example, based on the analysis of judicial practice on the protection of intellectual property rights, contradictory decisions on the relations of legal norms with the norms of contemporary Russian language are analyzed. A future expert should evaluate such names as "Ё-MÖ̈" ('YOMO'YO), “Ядрён Бидон” (Yad`ryon Bi`don), “Ёшкин кот" ('Yoshkin `kot), “ЁКЛМН" (YoKLMN) and similar, as conflictogenic ones and critically evaluate signs of conflictogenity in linguistic and creative nominator's activities.

Careful attention to commercial city nomination (name of cafes, restaurants, shops, beauty salons, residential complexes, fitness centers, etc.) in process of training of future experts is due to the fact that it is characterized by high linguistic creativity as a rule, creation of commercial urbanonyms is a result of creative-oriented speech of the nominator.

Both successful and unsuccessful urbanonyms, from a linguistic point of view, can become the subject of study. Thus, "quasitoponyms", commercial names which use word-formation models typical for Russian toponyms - Одёжкино (Odyozhkino), Обувкино (Obuvkino), Посудкино (Posudkino), Коляскино (Kolyaskino), Игрушкино (Igrushkino), can be regarded as the first ones (formation takes place by means of one of the most commonly used toponymic formants $-и н(о))$. 
From a pragmatic point of view, the creativity of nomination is justified as a potential buyer is informed not only about a specialization of a shop, but also about a large assortment of products offered.

Names such as Парижск (Parizhsk) can be regarded as the latter, unsuccessful ones. In the name of the café, a productive, native Russian topographical formant -ск is used, nevertheless, the cacophony of the urbanonym (a combination of three consonants) and its obvious artificiality does not allow us to consider it a success. However, in such cases, students can validate and defend their own point of view using arguments, since the pragmatic efficiency of an urbanonym is often ensured by its linguistic and creative character and does not always lead to conflictogenity.

It is this approach that provides the necessary amount of the basic special knowledge for Speech Studies examinations in a general and naming examination, in particular. The disciplines "General Linguistics and Contemporary Russian language", "Fundamentals of Applied and Mathematical Linguistics" prepare students for the next courses on Speech Studies, including "Linguistic Analysis" which is especially important in the aspect of naming examination competences (the workload of the discipline is 3 credits).

A successful acquisition of this discipline provides future experts with necessary knowledge of methodology of linguistic analysis of fiction, journalistic texts, voice products of officially-business and conversational style, that is, allows them to master the methodological tools of linguistic analysis. Widely using interactive forms of learning (case studies, aquarium technique, role plays, etc.), a teacher creates professional competence of a naming examination specialist in students. In drawing up cases, an electronic resource a base of trademarks (service marks) of the Federal Institute of Intellectual Property (FIIP) is used.

Thus, one of the cases sets out a particular naming situation (an applicant seeking to register a new trademark in Rospatent explains the verbal designation "ViРушка" (ViPushka) as consisting of the component ViP - "very important person" - and the ending "ушка"), formulates questions and tasks, encloses illustrations of the claimed designation, as well as guidelines for the analysis of trademarks and service marks.

Addressing this challenging task, students come to the following results: the following errors were detected in the description of the claimed designation:

- on the morphemic level (formant -ушка is not the ending, but contains the -ушк- suffix and the -a inflection);

- errors in the name's graphemic representation.

The application of knowledge of contemporary Russian language leads students to the conclusion that counting on the high status of the product associated with the semantics of the component "ViP" (Very Important Person) is not correct: the graphogibridization in the word "ViРушка" conditions pronunciation of the capital Latin grapheme "P" as the Russian "эр" (er) "ВИРУШКА" (VIR'USHKA) (this is the keyword which the automatic search system «Znakoved» produces upon this request). Leveling of the name's "high status" also occurs due to the addition of the suffix -ушк-, which in this case has not "diminutive" but disparaging meaning.

Much attention is paid to the form of presentation of results as a formalized coherent text by way of a fragment of professional judgment. The skill of drawing up a complete conclusion by a Speech Studies specialist will be practiced during the acquisition of subsequent specialization subjects. In addition, while working with cases, competencies of information technologies reception, processing and delivery of information, the mass media and multimedia technologies applied to the language of Internet communications - are also generated.

Formation of competences necessary for a naming examination specialist is finished by a discipline which is one of the main ones in the block of disciplines of the specialization "Forensic Linguistic Examination" [8]. It is as part of the program of the course (total labor input of 8 credits) that naming examination is acquired as a new type of forensic linguistic examination. At lectures, students are given the basics of the conceptual apparatus ("naming", "name", "title", "designation" and others), a subject, a object, the main tasks of naming examination are defined, the types of expert research of names are considered, the methodological foundations of naming examination are laid.

During the interactive conversation, a lecturer activates students' knowledge of the previously studied disciplines, both those related to Speech Studies ("General Linguistics and Contemporary Russian Language", "Fundamentals of Applied and Mathematical Linguistics", "Linguistic Analysis", etc.), and legal ones ("Intellectual Property Rights", "Patent Law" and others).

At workshops, and in the course of laboratory practical work in an interactive way, consolidation and expansion of the received knowledge take place, skills of naming examination production are acquired. In particular, the program includes practical training in the form of a role-playing game "A court session on intellectual property rights". A teacher develops a scenario and prepares case studies posted on the university's electronic resource.

Students are offered a description of a particular real conflict in the naming field, provided with documents and other materials of a particular case, related to protection of intellectual property rights. To ensure the competitiveness of litigation, different sides of a conflict prepare their professional judgment, and the court appoints an independent naming examination. In the course of a game (which involves all students) formation of professional competence (the ability to apply knowledge of substantive and procedural rights; the ability to apply the techniques of experience and research of speech, fixed on any tangible medium in any form, etc. in professional activities) takes place.

In addition, during a role-play the general cultural competences formed earlier as the ability to carry out oral and written communication in Russian; to logically correctly, clearly and in a well-argued manner build oral 
and written speech, to publicly present the results of research, to conduct debate and discussion (GC-13) are assessed.

In preparation for a role play, students' ability to work with different sources of information, information resources and technologies, use computers, application software, modern telecommunications, automated call centers, information retrieval systems, databases, workstations (GC-16) is assessed.

Experience has shown high efficiency of this interactive form of practical training, which is fixed by means of video and voice recording of the polylogue's verbal component, which allows accounting and a detailed analysis of the speech of each participant of the role-playing game.

Abilities and expert skills of a specialist in the field of naming examination are developed in laboratory practice. In particular, to perform laboratory work "Naming examination", the authors of the working program of the discipline "Forensic Linguistic Examination" proposed an algorithm of expert research of names, developed case studies for students' independent work on the acquisition of methods of analyzing names as specific types of speech products. Particular attention is paid to the analysis of urbanonyms, names of residential complexes - both creative and at the same time often contentious. E.g., see, the name of the RC (Residential complex) "Katrinhouse" («Катрин-хаус»), which does not meet the ethical criterion (the building is on the street named after pilot Ekaterina Budanova, Hero of the Great Patriotic War), as well as RC "Патриарх" ("Patriarkh", "Patriarch"), «Маршала Василевского» ("Marshala Vasilevskogo) ( The residential complex was named after Marshal Vasilevskii street, on which it is located, yet the genitive case used in Russian makes the name sound as if the building belonged to this person) and many others.

In conclusion, training of specialists in the field of forensic linguistic examination as a whole, with special knowledge to participate in the affairs on the protection of intellectual property rights as legal experts, plays an important role amid the active development of globalization processes and building of information society. In this new environment, the need for uniform internationally accepted approaches and standards for the creation, integration, use of results of intellectual activity, increases in legal protection, commercialization and protection of the rights to them.

The work was supported by the Russian Foundation for Humanities, grant 15-04-00282.

\section{References}

1. T.P.Sokolova, Neimingovaya ekspertiza: organizatsiya i proizvodstvo (Yurlitinform, Moskva, 2016) [In Rus]

2. T.P.Sokolova, Vestnik Universiteta imeni O.E. Kutafina, 12, 75 (2015) [In Rus]

3. E.R.Rossinskaya, Vestnik Universiteta imeni O.E. Kutafina, 12, 58 (2015) [In Rus]

4. E.I.Galyashina, Rossiiskoe pravo v Internete, 3 (2008) [In Rus]

5. E.I.Galyashina, Teoriya i praktika sudebnoi ekspertizy, 2 (2007) [In Rus]

6. E.R.Rossinskaya, E.I.Galyashina, A.M.Zinin,Teoriya sudebnoi ekspertizy, (Norma Infra-M, Moskva, 2015) [In Rus]

7. E.I.Galyashina, VestnikUniversitetaimeni O.E. Kutafina, 12, 38 (2015) [In Rus]

8.E.I.Galyashina. ZakonyRossii: opyt, analiz, praktika. 10, 17 (2015) [In Rus]

9. M.E.Rut, Obraznaya nominatsiya v russkoi onomastike (LKI, Moskva, 2008)[In Rus]

10. V.D. Bondaletov, Russkaya onomastika (Librokom, Moskva, 2012) [In Rus]

11. A.V.Superanskaya, V.E.Staltmane, N.V. Podol'skaya, A.Kh. Sultanov, Teoriya $i$ metodika onomasticheskikh issledovanii (LIBROKOM, Moskva, 2009) [In Rus]

12. A.V.Superanskaya, T.A. Soboleva, Tovarnyeznak (LIBROKOM, Moskva, 2009) [In Rus]

13. M.V. Golomidova, Iskusstvennaya nominatsiya $v$ russkoi onomastike (UGPI, Ekaterinburg, 1998) [In Rus] 14. I.V. Kryukova, Reklamnoe imya: ot izobreteniya do pretsedentnosti (Peremena, Volgograd, 2004) [In Rus]

15. E.N.Remchukova, T.P.Sokolova, L.R. Makhiyanova, Gumanitarnye, sotsial'no-ekonomicheskie obshchestvennye nauki, 9, 3 (2015) [In Rus]

16. T.P. Sokolova, Trudy Instituta russkogo yazyka im. V.V. Vinogradova, 7, 179 (2015) [In Rus]

17. E.N.Remchukova, L.R. Makhiyanova, Vestnik Rossiiskogo universiteta druzhby narodov, 2,132 (2015) [In Rus]

18. E.I.Galyashina, T.P.Sokolova, Sudebnaya lingvisticheskaya ekspertiza: rabochaya programma (MGYuA, Moskva, 2015) [In Rus] 